\title{
Lypsylehmät sopeutuivat hyvin siirtoon parsinavetasta automaattiseen lypsyjärjestelmään
}

\author{
Suvi Pekkanen ${ }^{1}$, Satu Rautaoja ${ }^{1}$, Risto Kauppinen ${ }^{1}$, Leena Ahola ${ }^{2}$, Jaakko Mononen $^{2}$, Petri \\ Kainulainen ${ }^{l}$ \\ 1 Savonia ammattikorkeakoulu, Iisalmi etunimi.sukunimi@savonia-amk.fi \\ 2 Soveltavan biotekniikan instituutti, Kuopion yliopisto etunimi.sukunimi@uku.fi
}

Tutkimuksessa tarkasteltiin lypsylehmien yksilöllistä sopeutumista siirryttäessä suoraan parsinavetasta pihaton automaattiseen lypsyjärjestelmään. Tutkimus toteutettiin tapaustutkimuksena lämminpihatossa kevään ja syksyn 2004 välisenä aikana sekä kyselytutkimuksena 16 tilalle, jotka olivat siirtyneet suoraan parsinavetasta automaattiseen lypsyjärjestelmään. Suurin osa lehmistä tottui nopeasti uuteen lypsyjärjestelmään. Lehmien totuttamiseen tarvittiin jonkun verran ylimääräistä työtä kahden ensimmäisen viikon aikana siirron jälkeen. Työ oli lähinnä lehmien ajamista robotille.

\section{Tapaustutkimus}

Tapaustutkimuksessa 28 ayshire lehmää siirrettiin suoraan parsinavetasta pihattoon ja robottilypsyyn. Pihattoon siirrettyjen lehmien annettiin ensin tutustua rauhassa uuteen ympäristöön. Totutettaessa lehmiä robotille houkutusrehua oli jatkuvasti tarjolla. Tarvittaessa lehmiä ajettiin, vedettiin ja työnnettiin robotille. Lehmien käyttäytymistä tarkkailtiin suoralla seurannalla (focal sampling) niiden mennessä robotille kahdeksalla lypsykerralla neljän päivän ajan. Pelkkiä robotin läpikulkukertoja ei huomioitu laskennassa.

Kaksikymmentä lehmää käyttäytyi rauhallisesti ja pelottomasti heti ensimmäisestä robotilla käyntikerrasta lähtien. Kuudennella lypsykerralla kirjattiin havainnot 18 lehmästä, joista yhtä vaille kaikki kulkivat robotille joko aivan itsenäisesti tai vaativat vain vähäistä ajamista. Kaksi viikkoa robotin käyttöönoton jälkeen kaikki lehmät kävivät robotilla ilman ajamista

\section{Kyselytutkimus}

Kyselytutkimus tehtiin 16 tilalle, jotka olivat siirtyneet suoraan parsinavetasta automaattiseen lypsyjärjestelmään. Kyselytutkimus tuki tapaustutkimuksen havaintoja. Vastausten mukaan lehmät suhtautuivat lypsyrobottiin uteliaasti. Parsinavetasta automaattiseen lypsyjärjestelmään siirryttäessä $80 \%$ lehmistä tottui uuteen järjestelmään helposti.

Lehmiä oli totutettu lypsyrobottiin ajamalla (11 tilaa), rehulla houkuttelemalla (7), vetämällä (3) ja jollakin muulla tavalla (5). Muita tapoja olivat lehmän työntäminen lypsyrobottiin sekä lehmien vieminen navettaan ennen lypsyrobotin käyttöönottoa. Yhdellä tilalla lehmiä totutettiin pyyhkimällä niiden utareita lypsypyyhkeellä ennen robottilypsyä, jotta lehmällä olisi lypsytapahtumassa jotain tuttua. Useilla tiloilla käytettiin useita totutustapoja yhtäaikaisesti, jotta tottuminen nopeutuisi. Ensikoiden ja vanhempien lehmien tottumisessa robottiin ei ollut vastausten mukaan suuria eroja. Yksi tai useampi lehmä poistettiin joka toisella tilalla automaattiseen lypsyjärjestelmään siirryttäessä. Yleisin poiston syy oli matala, robottiin sopimaton utarerakenne.

Avainsanat: automaattilypsy, sopeutuminen, parsinavetat, pihatot 


\section{Johdanto}

Automaattiset lypsyjärjestelmät ovat yleistyneet Suomessa viimeisen viiden vuoden aikana räjähdysmäisesti. Ensimmäiset lypsyrobotit ovat lypsäneet Suomessa vuodesta 2000. Tällä hetkellä lypsyrobottien määrä yhteensä kaikkien merkkien osalta on lähes kaksi sataa. Lypsyroboteista alkaa olla käyttäjäkokemuksia ja niistä on olemassa jonkin verran tieteellisiä tutkimuksia. Näissä tutkimuksissa on kuitenkin yleensä keskitytty robotin toimintaan sekä maidon laatuvaihteluihin. Lehmien näkökulmasta tutkimuksia on tehty Suomessa vain yksi, Suitian opetus- ja tutkimustilalla vuonna 2000, jossa tutkittiin lehmien käyttäytymistä automaattilypsyssä (Raussi \& Kaihilahti 2001a, b). Lehmäkohtaista tottumista automaattilypsyyn ei ole tutkittu. Lypsyrobottia harkitsevat tuottajat ovat varmasti pohtineet, miten heidän lehmänsä tottuvat täysin toisenlaiseen lypsytekniikkaan? Lypsyrobotti on kallis investointi ja tarkkaa tietoa käytännön tiloilta lehmien tottumisesta ei ole ollut tätä ennen. Tuottaja, joka on harkitsemassa näin isoa muutosta, on kiinnostunut aiemmin robotin hankkineiden käyttäjäkokemuksista jo hyvissä ajoin ennen hankintaa. Selvityksen alkuvaiheessa tehdyssä kyselyssä kävi ilmi, että tietoa lehmien tottumisesta lypsyrobottiin ei ole ollut saatavilla, kun tuottajat olivat hankkimassa lypsyrobottia. Tutkimuksen tavoitteena oli selvittää missä ajassa lehmät tottuvat lypsyrobottiin niin, että ne kulkeutuvat sinne vapaaehtoisesti, onko ensikoiden tottumisessa lypsyrobottiin eroa vanhempiin lehmiin verrattuna, mitkä ovat lehmien robotilta poistojen syyt ja tottuvatko kaikki lehmät robottiin?

Tiedot kerättiin posti- ja puhelinkyselynä tiloilta, jotka olivat siirtyneet suoraan parsilypsystä ja parsinavetasta pihattoon ja DeLavalin lypsyrobottiin. Tämän lisäksi työssä tehtiin selvitys Haapajärven ammatti-instituutin koulutilan uudessa lypsyrobottinavetassa, jossa selvitettiin miten parsilypsyyn tottuneet lehmät tottuivat automaattilypsyyn. Selvityksessä tarkasteltiin lehmäkohtaisesti, kuinka ensimmäiset lypsykerrat robotilla sujuvat. Tietoa saatiin havainnoimalla lehmiä toukokuusta elokuuhun ja täyttämällä lehmäkohtaisia tottumiskortteja lehmien ensimmäisiltä lypsykerroilta. Haapajärven ammatti-instituutin navetta on ainutlaatuaan Suomessa. Navetassa on lypsyrobotin ohella toiminnassa lisäksi kolmepaikkainen kalanruoto lypsyasema, sekä perinteinen parsilypsyjärjestelmä.

\section{Aineisto ja menetelmät}

Tutkimus toteutettiin huhtikuun ja elokuun 2004 välisenä aikana. Tutkimus jaettiin kahteen osaan, tuottajille suunnattuun kyselytutkimukseen ja koulutilalla suoritettuun tapaustutkimukseen.

\section{Kyselytutkimus}

Kyselytutkimukseen valittiin mukaan parsinavetasta DeLavalin VMS-järjestelmään siirtyneet tilat. Huhtikuussa 2004 tällaisia tiloja oli 16, joista yksi kieltäytyi vastaamasta. Näin ollen kyselyyn saatiin mukaan 99 \% Suomen VMS-lypsyrobottitiloista, jotka olivat siirtyneet parsilypsystä suoraan pihattoon ja automaattilypsyyn. Tiloille lähetettiin kysely, jonka vastaukset kerättiin puhelimitse noin viikkoa myöhemmin. Vastaukset kirjattiin samanlaiselle lomakkeelle kuin minkä tilat olivat saaneet postitse. Kyselyssä tiedusteltiin eläinten sopeutumista uuteen lypsyjärjestelmään, totuttamistapoja, tottumisaikoja, poiston syitä sekä eläimen iän vaikutusta sopeutumiseen.

\section{Tapaustutkimus}

Tapaustutkimus toteutettiin Haapajärven ammatti-instituutin uudessa pihatossa. Tutkimuksen alussa mukana oli 28 lehmää, joista 19 oli lypsyssä. Lehmät siirrettiin siirtopäivän aamuna uuteen navettaan ja niiden annettiin tutustua rauhassa uuteen ympäristöön. Laumahierarkia oli muodostunut jo aiemmin, sillä lehmät olivat ulkoilleet läpi talven jaloittelutarhassa ja selvittäneet lauman arvojärjestyksen. Lehmien tottumista edesautettiin houkutusrehun avulla sekä ajamalla. Kulkureittien oppimista edistettiin mm. köyttämällä paluunestoportit hieman auki. Lehmien annettiin kulkea robotin läpi itsenäisesti kaksi kertaa ennen kuin robotti otettiin varsinaisesti käyttöön. Myös tällä edesautettiin eläinten tottumista uuteen järjestelmään.

Lehmiä havainnoitiin yksilöllisesti kahdeksalla ensimmäisellä robotilla käyntikerralla. Havainnot kirjattiin lomakkeelle. Robotin läpikulkukertoja ei laskettu havainnoiksi. Havaintoja tehtiin neljän päivän ajan muutosta. Lehmien tottumista selvitettiin $\mathrm{mm}$. havainnoimalla, miten lehmien kulku robotille tapahtui. Kulkemista arvioitiin asteikolla $1-5$, jossa $1=$ helppo ja $5=$ vaikea. Lisäksi arvioitiin sitä, miten lehmä suhtautui robottiin, miten lehmän käyttäytyi robotilla sekä miten se poistui robotilta. Lehmille tarjottiin robotilla houkutusrehua noin $2 \mathrm{~kg} / \mathrm{päivä.}$ 


\section{Tulokset ja tulosten tarkastelu}

\section{Kyselytutkimus}

Kyselyyn osallistuneista tiloista seitsemällä oli automaattilypsyn käynnistyessä alle 30 lehmää, kuudella tilalla oli 31 - 50 lehmää ja ainoastaan kahdella tilalla lehmiä oli yli 50. Seitsemällä tilalla lehmiä houkuteltiin robotille rehun avulla, kymmenellä tilalla lehmiä ajettiin ja kolmella tilalla vedettiin robotille. Muita tapoja käytti viisi tilaa. Näitä muita tapoja oli $\mathrm{mm}$. lehmien vieminen navettaan ennen robotin käyttöönottoa sekä utareiden pyyhkiminen ennen lypsyä. Valtaosalla tiloista käytettiin samanaikaisesti useaa eri totuttamistapaa yhtäaikaisesti, jotta tottuminen olisi nopeampaa (Kuvio 1).

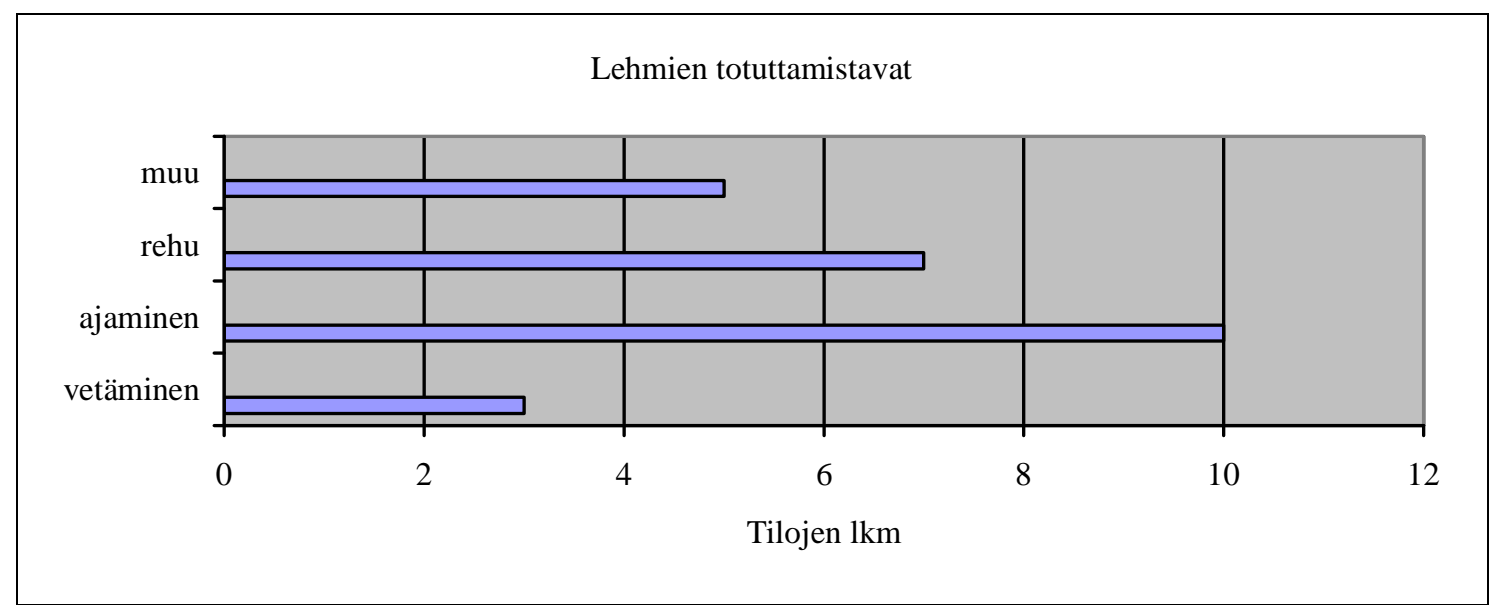

Kuvio 1. Lehmien lypsyrobotille totuttamistavat

12 tiloista lehmiä houkuteltiin tai ajettiin lypsyrobotille alle kaksi viikkoa, missä ajassa tottumista voitiin todeta tapahtuneen. Yhdeksällä tilalla ensimmäinen lehmä alkoi käydä itsenäisesti robotilla jo ensimmäisen käyttöönottovuorokauden aikana. Viidellä tilalla kaikki lehmät oppivat käymään robotilla itsenäisesti 14 päivässä, kuudella tilalla 15 - 30 päivässä ja neljällä tilalla vasta 60 päivässä tai sen jälkeen. Kaikkiaan 12 tiloista kaikki lehmät tottuivat lypsyrobottiin ja kolmella tilalla osa ei tottunut robottiin. Tottumattomuuden syiksi arveltiin sopeutumattomuutta, arkuutta ja huonoa luonnetta.

Yhtä tilaa lukuun ottamatta lehmille tarjottiin robotilla houkutusrehua ja se havaittiin hyväksi totuttamiskeinoksi. Tilalta, jolla rehu ei ollut käytössä, jouduttiin poistamaan kaiken kaikkiaan 10 lehmää. Kahdeksalla tilalla lehmiä ei jouduttu poistamaan lainkaan robotin takia, viidellä tilalla 1-4 lehmää poistettiin sopimattoman utarerakenteen takia, kahdella tilalla lehmän luonteen takia ja yhdellä tilalla utaretulehduksen takia.

Ensikoiden ja vanhempien lehmien tottumisessa ei havaittu isoa eroa. Kahdeksalla tilalla ensikoiden todettiin tottuneen hieman vanhempia nopeammin, kun taas seitsemällä tilalla ei näiden kahden ryhmän välillä havaittu eroa. Lehmien suhtautuminen robottia kohtaan oli pääsääntöisesti uteliasta. 12 tilalla lehmät eivät osoittaneet pelokkuutta lypsyrobottia kohtaan (Kuvio 2). Kaikki tilat olivat tyytyväisiä lehmien lypsyrobotille tottumiseen. 


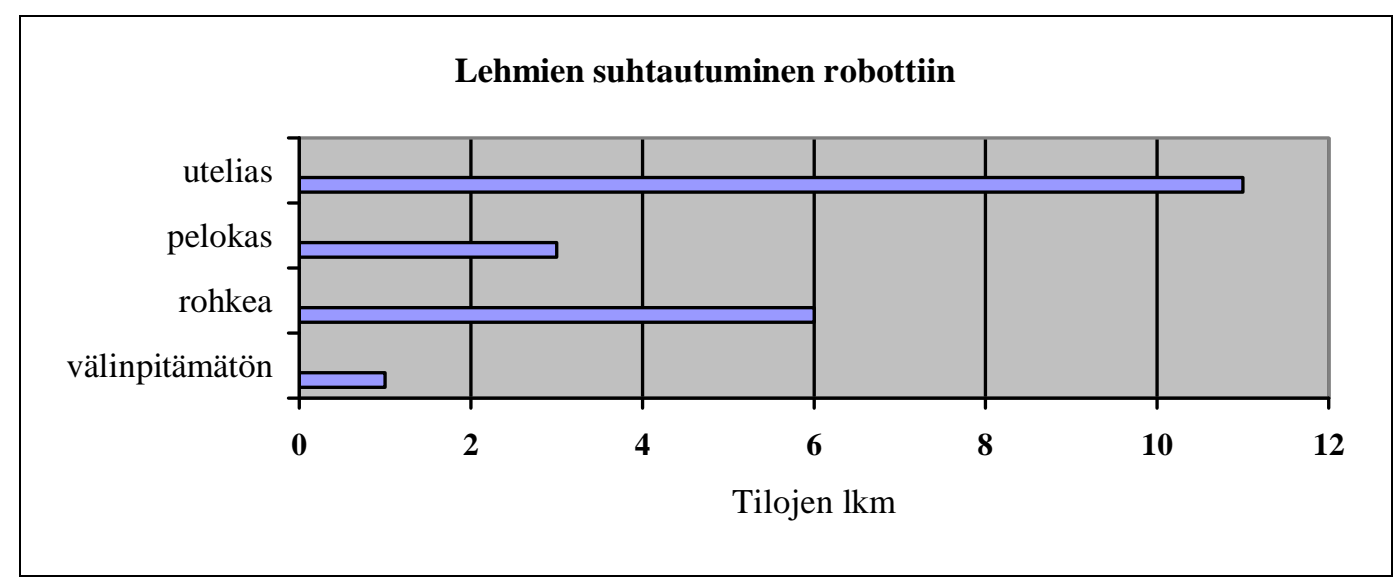

Kuvio 2. Lehmien suhtautuminen lypsyrobottia kohtaan tiloilla

\section{Tapaustutkimus}

Kesän 2004 aikana havainnoitiin yhteensä 25 lehmää. Ensimmäisellä kerralla vapaaehtoisesti robotille kulki yksi lehmä, ajamalla 23 lehmää ja vetämällä kuusi lehmää. Useampaa totutuskeinoa voitiin kuitenkin käyttää samanaikaisesti. 13 lehmää kulki ensimmäisellä kerralla robotille erittäin helposti tai helposti (arvoasteikko 1-2). Erittäin vaikeasti tai vaikeasti robotille meni kuusi lehmää (arvoasteikko 4-5) (Kuvio 3). Samoin 13 lehmää suhtautui uteliaasti robottia kohtaa, pelokkaita oli 10 lehmää ja hermostuneita oli seitsemän. Aggressiivisuutta robottia kohtaan ei havaittu lainkaan ensimmäisellä kerralla. 18 lehmää käyttäytyi rauhallisesti robotilla, kuuden lehmän kohdalla oli havaittavissa pelokkuutta. Hermostuneisuutta esiintyi viidellä lehmällä ja yksi käyttäytyi aggressiivisesti lypsettäessä. Ensimmäisellä lypsykerralla seitsemän lehmää potki robotin käsivartta pesuvaiheessa ja kuusi lehmää lypsyvaiheessa. 21 lehmää poistui robotilta rauhallisesti, kolme lehmää jouduttiin ajamaan pois ja yksi poistui ryminän kanssa.

Kolmannelta lypsykerralta on tiedot 21 lehmästä. Tällöin vapaaehtoisesti robotille kulki kuusi lehmää, 15 lehmää ajettiin ja kolme lehmää vedettiin robotille. 17 lehmää sai robotille kulkemisesta arvion 1-2 ja kolme lehmää arvion 4-5 (Kuvio 3). Yhdeksän lehmää suhtautui uteliaasti, pelokkaita oli kymmenen, hermostuneita kolme ja aggressiivisia ei yhtään. 19 lehmän osalta lypsytapahtuma sujui rauhallisesti, pelokkaita oli kaksi ja hermostuneita neljä. Yhtä lehmää lukuun ottamatta kaikki lehmät söivät robotilla houkutusrehua. Pesuvaiheessa käsivartta potki neljä lehmää, lypsyvaiheessa kolme lehmää ja desinfiointivaiheessa kaksi lehmää. Lypsyn päätyttyä rauhallisesti robotilta poistui 19 lehmää ja kaksi jouduttiin ajamaan pois.

Kuudennelta lypsykerralta on tiedot 18 lehmästä. Tällöin vapaaehtoisesti robotille kulki 11 lehmää, 10 lehmää ajettiin ja kaksi lehmää jouduttiin vetämään robotille. Kulkemisesta robotille arvion 1-2 sai 17 lehmää (Kuvio 3). 11 lehmää suhtautui uteliaasti robottia kohtaan, pelokkaita oli kolme ja hermostuneita kolme lehmää. 15 lehmää käyttäytyi lypsyn aikana rauhallisesti, hermostuneita oli kaksi ja yksi arvioitiin aggressiiviseksi. Neljä lehmää potki robotin käsivartta pesuvaiheessa ja kaksi lehmää lypsyvaiheessa. Lypsyn päätyttyä 17 lehmää poistui robotilta rauhallisesti ja yksi jouduttiin ajamaan pois. 


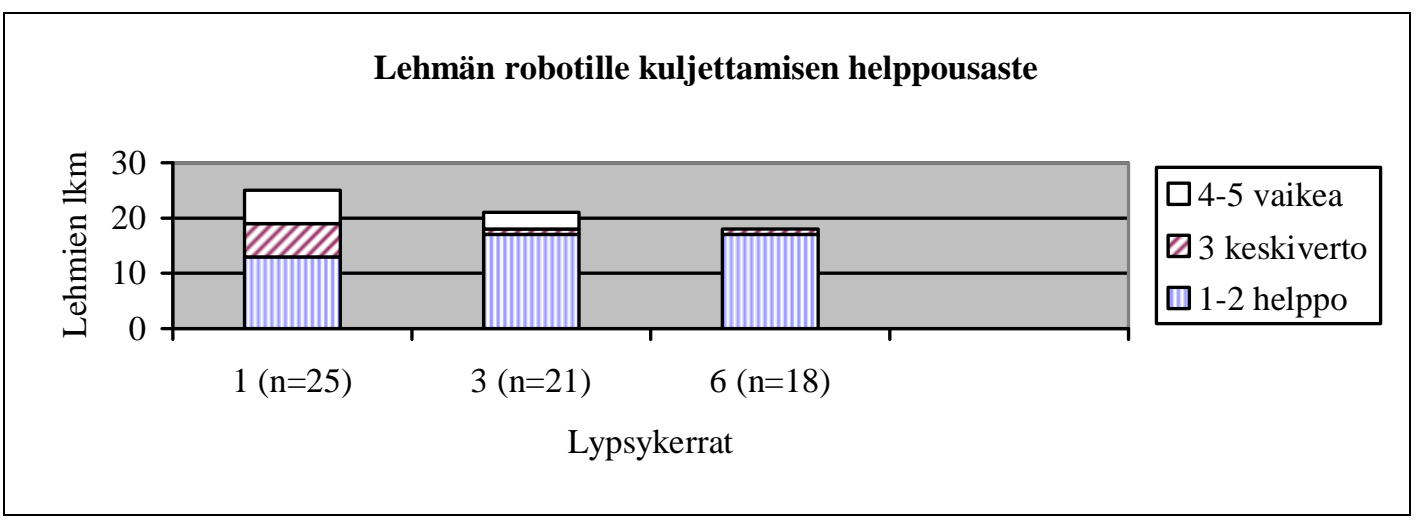

Kuvio 3. Lehmien kuljettamisen helppouden muutokset havainnoinnin aikana

Lehmien tottumiseen käytetyt keinot ja saavutetut tulokset on esitetty taulukossa 1. Tästä voidaan havaita, että selvää tottumista tapahtuu jo kuuden ensimmäisen lypsykerran aikana. Tarve ajamiseen vähenee ja vapaaehtoisesti robotille menevien määrä lisääntyy.

Taulukko 1. Lypsyrobotille totuttamiseen käytetyt keinot ja saavutetut tulokset 28 lehmän karjassa.

\begin{tabular}{|c|l|l|l|l|}
\hline Tarkkailukerta & Ajaminen & Vetäminen & Vapaaehtoinen & \multirow{2}{*}{$\begin{array}{l}\text { Houkutusrehu } \\
\text { jatkuvasti tarjolla }\end{array}$} \\
\cline { 1 - 4 } & 23 lehmää & 6 & 1 & \\
\cline { 1 - 4 } & 15 & 3 & 6 & \\
\hline 6 & 10 & 2 & 11 & \\
\hline
\end{tabular}

Haapajärven koulutilalta ei alun perin poistettu yhtään lehmää huonon utarerakenteen vuoksi. Yksi lehmä jouduttiin kuitenkin poistamaan myöhemmin, sillä utare oli matala ja iso eikä robotti kyennyt sitä kunnolla lypsämään. Tämä johti toistuvaan utaretulehdukseen ja lehmä poistettiin. Myös toinen lehmä poistettiin myöhemmässä vaiheessa utaretulehduksen takia. Valtaosalla lehmistä, joilla ongelmia esiintyi esim. nännikuppien kiinnityksen kanssa, ongelma poistui muutamassa viikossa utareen turvotuksen laskettua. Luonteen takia karjasta poistettiin kaksi lehmää, jotka käyttäytyivät jatkuvasti aggressiivisesti robotilla. Nämäkin lehmät kuitenkin hakeutuivat aktiivisesti ja vapaaehtoisesti lypsylle.

Koulutilalla tarkkailtiin lisäksi lehmien rauhallisuutta lypsyssä ennen ja jälkeen siirron. Seitsemän lehmää, jotka olivat käyttäytyneet erittäin rauhallisesti parsilypsyssä, olivat rauhallisia jo ensimmäisellä robottilypsykerralla. Ainoastaan yksi parsilypsyssä rauhallisesti käyttäytynyt eläin oli robotilla ensimmäistä kertaa lypsettäessä rauhaton. Kuudenteen kertaan mennessä kaikki lehmät, jotka olivat käyttäytyneet rauhallisesti parsilypsyssä, käyttäytyivät rauhallisesti myös robottilypsyssä. Havaittavissa oli myös, että sellaiset lehmät, jotka käyttäytyivät rauhattomasti parsilypsyssä, tottuivat robottiin ja oppivat käyttäytymään siinä rauhallisesti.

\section{Johtopäätökset}

Sekä kyselytutkimuksesta että tapaustutkimuksesta saatujen tulosten perusteella kahta viikkoa voidaan pitää aikana, jona valtaosa lehmistä tottuu lypsyrobotin tuomiin muutoksiin. Yksilöllistä tottumista havaitaan jo ensimmäisten neljän päivän aikana siirrosta. Kyselyyn vastanneista 15 tilasta 12 tilalla kaikki lehmät tottuivat lypsyrobottiin. Alle puolet tiloista joutui poistamaan lehmiä, yleensä johtuen utareen lypsyrobottiin sopimattomasta rakenteesta. Myös tapaustutkimuksessa tämä oli poiston syy. Lehmien tottumista edistää houkutusrehun käyttö ja hoitajien kärsivällisyys lehmien ajamiseen ja vetämiseen. Sopeutumista voidaan tehostaa myös antamalla lehmille mahdollisuus tutustua uuteen ympäristöön ilman, että itse robotti on toiminnassa tai tuomalla lypsytapahtumaan jotain aiemmasta tuttua esim. utareiden pyyhkiminen. Lauman sisäiset konfliktit voidaan välttää suorittamalla siirto laidunkauden aikana tai sen päättyessä. Erityisesti parsinavetasta pihattoon siirryttäessä tämä helpottaa ihmistyötä huomattavasti. Lehmiä totuttaessa tulee kuitenkin muistaa, että jokainen lehmä on yksilö ja 
myös sillä saattaa olla huono päivä, joka näkyy käyttäytymisessä lypsyrobottia kohtaan. Koko karjan tottuminen lypsyrobottiin riippuu paljon tilojen totutustavoista ja karjanhoitajien tavoista käsitellä eläimiään.

\section{Kirjallisuus}

Raussi, S, Kaihilahti, J. 2001a. Lehmän hyvinvointi automaattisessa lypsyssä. Nauta5/2001. Helsinki: ISPRINT OY. 15.

Raussi, S, Kaihilahti, J. 2001b. Lehmän käyttäytymisestä automaattisessa lypsyjärjestelmässä. Koekukko vol.21 2/2001. Savon kopiokeskus. 18. 